PSYCHOLOGIA ROZWOJOWA, $2019 *$ tom 24, nr 3, s. 99-102

doi:10.4467/20843879PR.19.025.11731

www.ejournals.eu/Psychologia-Rozwojowa

BEATA WINNICKA (iD) orcid.org/0000-0002-0392-6699

Instytut Psychologii, Akademia Ignatianum, Kraków Institute of Psychology, Jesuit University Ignatianum in Cracow e-mail: beata.winnicka@ignatianum.edu.pl

\title{
Recenzja książki: Mark H. Johnson, Michelle de Haan (2018), Neurokognitywistyka rozwoju. Wprowadzenie. Gdańsk: Harmonia Universalis
}

Recenzowana książka jest tłumaczeniem czwartego wydania książki Developmental Cognitive Neuroscience, która po raz pierwszy ukazała się w 1997 roku. Ze względu na dynamiczny rozwój neurokognitywistyki w ostatnich dwóch dekadach, który zaowocował bardzo licznymi pracami publikowanymi w czasopismach ogólnych i specjalistycznych, autorzy zdecydowali się po raz kolejny uaktualnić prezentowane treści, uwzględniając między innymi epigenetykę oraz problematykę genetycznego podłoża procesów rozwojowych. Wzięli również pod uwage rosnące zainteresowanie zastosowaniem przedstawianej wiedzy w rozwiązywaniu problemów praktycznych, dodając rozdział poświęcony neuronauce w edukacji. Autorzy zaadresowali książkę do szerokiego grona odbiorców - zarówno naukowców zajmujących się dyscyplinami pokrewnymi i zazębiającymi się z neurokognitywistyką rozwoju, jak i studentów oraz obecnych i przyszłych specjalistów w dziedzinach psychologii klinicznej dziecka, psychiatrii i pedagogiki, zaznaczając przy tym, że zrozumienie przedstawionych w niej treści wymaga znajomości podstawowej wiedzy z zakresu neurobiologii i rozwoju poznawczego. Książka została pomyślana jako krótkie wprowadzenie do neurokognitywistyki rozwoju, zogniskowane na osiowym pytaniu o związek pomiędzy rozwojem ludzkiego mózgu a wyłaniającymi się procesami poznawczymi. Autorzy zakreślają obszar przedstawianej dyscypliny, wskazując, że w przeciwieństwie do neuropsychologii i psychopatologii rozwoju koncentruje się ona na rozwoju typowym, a dane dotyczace nietypowych ścieżek rozwoju wykorzystuje przede wszystkim w dociekaniach o mózgowym podłożu prawidłowych procesów poznawczych.

Publikacja składa się z czternastu rozdziałów poprzedzonych przedmową do wydania polskiego, a także pierwszego i czwartego wydania książki w wersji anglojęzycznej, które ukazało się w 2015 roku. Przywołana literatura źródłowa (67 stron) zawiera przede wszystkim pozycje z ostatnich trzech dekad, choć pojawiają się też opracowania wcześniejsze. Lekturę książki ułatwiają obszerny indeks, bardzo użyteczny spis stosowanych skrótów oraz czarno-białe (w tekście) i kolorowe (na końcu książki) ryciny. W każdym z rozdziałów pojawiają się propozycje lektur uzupełniających. Książka stanowi przejrzystą, spójną całość. Autorzy prowadzą czytelnika przez swoją narrację według przemyślanego planu oraz wskazują na powiązania między poruszanymi zagadnieniami. Poszczególne rozdziały mają podobny układ. Rozpoczyna je część wprowadzająca, a kończy podsumowanie przedstawionych treści wraz z płynącymi z nich wnioskami. Rozdziały zwieńczają propozycje zagadnień do dyskusji.

Rozdział pierwszy, zatytułowany Biologia zmiany, został poświęcony zagadnieniom podstawowym dla neurokognitywistyki rozwoju. Autorzy podkreślają, że badania nad rozwojem muszą mieć charakter wielodyscyplinarny. Przedstawiają między innymi etologię jako ważne uzupełnienie neuronauki, wyrażając nadzieję, że połączenie obu dziedzin może odmienić sposób myślenia o podstawowych zagadnieniach rozwoju percepcyjnego i poznawczego. Opisuja 
maturacyjną koncepcję rozwoju psychicznego, sygnalizując, że nie wyjaśnia ona w pełni zagadnień rozwoju funkcjonalnego ludzkiego mózgu. Podejście maturacyjne zestawiają $\mathrm{z}$ ujęciem konstruktywistycznym, przedstawiając główne założenia specjalizacji interakcyjnej. Przywołują również koncepcję nabywania umiejętności, zaznaczając, że jest ona zgodna ze specjalizacją interakcyjną, a niejednokrotnie z obu ujęć wynikają podobne hipotezy.

Rozdział drugi poświęcono metodom badawczym oraz populacjom badanym w neurokognitywistyce rozwoju. Autorzy wskazują, że pojawienie się i udoskonalenie w ostatnich dekadach nowych technologii, w szczególności okulografii i metod obrazowania pracy mózgu, przyczyniły się do znacznego postępu w opisywanej dyscyplinie. Postęp technologiczny umożliwił prowadzenie badań $\mathrm{z}$ udziałem ludzi zamiast zwierząt, chociaż wciąż wykorzystuje się je na przykład w badaniach uwzględniających manipulacje materiałem genetycznym. Oprócz dzieci rozwijających się typowo w badaniach uczestniczą również osoby z autyzmem, zespołem Williamsa czy ADHD, obciążone wysokim rodzinnym ryzykiem zaburzeń, doświadczające we wczesnym dzieciństwie deprywacji sensorycznej lub wychowujące się w ubóstwie.

Rozdział trzeci, zatytułowany Od genu do mózgu, autorzy poświęcili zagadnieniu genetyki rozwoju, przedstawiając współczesne poglądy na temat udziału genów i ich struktury w budowaniu mózgu, a także ich oddziaływaniu na procesy poznawcze. Epigeneza jest według autorów ścieżką zarazem bardzo złożoną i zmienną. Jako sposób na radzenie sobie z przytłaczającą złożonością poruszanych zagadnień autorzy podają cztery strategie umożliwiające wyjaśnienie wpływu genów na procesy rozwoju funkcji mózgu: badanie roli odgrywanej przez cząsteczki będące bezpośrednimi produktami ekspresji genów, badanie osób rozwijających się typowo pod kątem zróżnicowania w zakresie genów, funkcji mózgu i procesów poznawczych, badanie zespołów zaburzeń wynikających $\mathrm{z}$ różnic genetycznych lub konkretnych osób z rzadkimi mutacjami oraz konstruowanie modeli zwierzęcych. W celu zilustrowania wyzwań związanych z próbami zintegrowania genetyki z neurokognitywistyką rozwoju badacze przedstawiają historię badań nad genem FOXP2. Podsumowując badania nad rozwojem ludzkiego mózgu, autorzy wskazują na specyficznie aspekty jego rozwoju: wzorzec rozwoju warstw kory od wewnatrz do zewnatrz oraz różnice w czasie rozwoju jej poszczególnych obszarów. Wyróżnione aspekty wiążą się z wydłużonym okresem rozwoju postnatalnego mózgu człowieka w porównaniu z mózgami zwierząt.

$\mathrm{W}$ rozdziale czwartym, zatytułowanym Mózg $w$ budowie, autorzy przyglądają się zagadnieniu pre- i postnatalnego rozwoju mózgu. Rozważając problem różnicowania się obszarów w korze nowej, omawiają między innymi koncepcje protomapy i protokory, przychylając się do poglądu pośredniego, zgodnie z którym uprzedniej specyfikacji podlegają obszary mózgu w dużej skali, a obszary funkcjonalne w małej skali kształtują mechanizmy zależne od aktywności. Zadają też ważne dla dalszych badań pytania dotyczące powiązania kształtującego się zróżnicowania strukturalnego mózgu z wyłanianiem się poszczególnych funkcji.

Kolejne rozdziały zostały poświęcone zmianom związanym z rozwojem układu nerwowego w poszczególnym sferach rozwoju percepcyjnego, poznawczego i ruchowego. Autorzy rozważają rozwój widzenia, orientowania się i uwagi, spostrzegania i działania w świecie przedmiotów i w świecie społecznym, uczenia się i pamięci długotrwałej, języka, pamięci roboczej i podejmowania decyzji oraz lateralizacji mózgu. Wskazują na rysujące się w neurokognitywistyce rozwoju możliwości powiązania miar obrazowania funkcjonalnego $\mathrm{z}$ informacjami behawioralnymi, hormonalnymi i genetycznymi.

W rozdziale dwunastym autorzy zastanawiają się nad możliwościami zastosowania neuronauki w edukacji. W nabywaniu umiejętności szkolnych, takich jak piśmienność czy umiejętności liczbowe, zachowują podział na umiejętności specyficzne i niespecyficzne dla dziedziny. Podkreślają stopniowe wycofywanie się procesów niespecyficznych dla dziedziny, związanych z zaangażowaniem obszarów przedczołowych mózgu. Opisują nietypowości obserwowane w mózgach uczniów z dysleksją i dyskalkulia, podkreślając, że nie jest jasne, czy 
są one przyczyną, czy też skutkiem zaburzeń. Wskazują zadanie na przyszłość, jakim będzie bardziej efektywne powiązanie prac laboratoryjnych z zakresu neuronauki z ich zastosowaniem w edukacji.

Rozdział trzynasty poświęcono koncepcji specjalizacji interakcyjnej, której autorem jest Mark H. Johnson ${ }^{1}$. Opisywana koncepcja wyjaśnia zmiany rozwojowe w postnatalnym rozwoju funkcji kory, takie jak lokalizacja i specjalizacja. Autorzy opisują mechanizmy leżące u podłoża specjalizacji interakcyjnej oraz rozważają ich wybrane konsekwencje funkcjonalne. Wskazuja na związek procesów utraty synaps i obwodów ze wzrostem specyficzności funkcjonowania mózgowego i poznawczego. Opisują mechanizm rozwoju zwany parcelacją, polegający na wzroście kapsułkowania, czyli izolowania informacji w obwodach mózgowych, skutkujący redukcją interferencji i wymiany informacji między poszczególnymi systemami mózgowymi. Jako ważne wyzwanie dla neurokognitywistyki rozwoju akcentują dociekania dotyczące sposobu, w jaki wchodzące ze sobą w interakcje sieci obszarów wyłaniają się w rozwoju postnatalnym. Autorzy wskazują na istotne zmiany w strukturze sieci zachodzące w rozwoju, takie jak wzrost w zakresie funkcjonalnych połączeń długodystansowych w mózgu, wyłonienie się hierarchicznej struktury połączeń, zdominowanej przez korę przedczołową, czy zmniejszanie się łączności między strukturami korowymi i podkorowymi. Większa łączność między tymi strukturami, obserwowana u osób w młodszym wieku, może, według autorów, wskazywać na dominującą rolę takich struktur, jak na przykład hipokamp czy ciało migdałowate w specjalizacji wybranych obszarów korowych. Autorzy uważają poszukiwanie odpowiedzi na pytanie dotyczące sposobu wyłaniania się sieci mózgowych w pierwszych latach życia za największe wyzwanie dla neurokognitywistyki rozwoju w najbliższych latach.

W ostatnim rozdziale książki autorzy podejmują próbę połączenia wątków podjętych w poszczególnych częściach książki, będącą podstawą sformułowania dalszych kierunków badań. Powracają do związku genów z rozwojem poznawczym, wskazując, że struktura mózgu jest wynikiem złożonych, samoorganizujących się procesów integracyjnych. Podkreślają zaobserwowaną w badaniach rozbieżność między rozwojem strukturalnym a funkcjonalnym, wskazując, że koncepcja epigenezy probabilistycznej, postulująca istnienie dwukierunkowych interakcji między rozwojem mózgu a rozwojem poznawczym, pozwala lepiej zrozumieć uzyskane wyniki niż epigeneza predeterminowana. Autorzy uznają modele sieci neuronalnych za doskonałe narzędzia badawcze, które po połączeniu architektury sieci z informacjami dotyczącymi struktury mózgu mogą stać się ważnym łącznikiem pomiędzy neurobiologią a psychologią poznawczą. Podkreślają przy tym, że modele powinny być tworzone na odpowiednim poziomie abstrakcji, tak aby mogły powiązać dane mózgowe i poznawcze.

Autorzy wyrażają przekonanie, że odwoływanie się do obliczeń mózgowych sprzyja lepszemu zrozumieniu rozwoju poznawczego. Wskazuja jednocześnie, że podejście neurokontruktywistyczne, które obrali, a w szczególności przyjęcie bardziej „etologicznego" poglądu na rozwój poznawczy, zmienia rodzaje reprezentacji rozważane w modelach rozwoju poznawczego. Pojawia się potrzeba wykorzystania mniej szczegółowych modeli, próbujących uchwycić funkcjonowanie kilku systemów mózgowych w danym obszarze, na przykład uwzględniających całą ścieżkę neuropoznawczą od wejściowych danych zmysłowych do wyjściowych informacji ruchowych. Rozważane reprezentacje mogą być zubożone $\mathrm{w}$ takim stopniu, aby poziom ich szczegółowości był wystarczający do adaptacyjnego zachowania w danym kontekście.

Neurokonstruktywizm, jak dowodzą autorzy, ma też implikacje dla rozumienia zaburzeń rozwoju, w których powiązania pomiędzy mózgiem a systemem poznawczym są zwykle bardzo nieoczywiste. Liczne zakłócenia funkcji mózgu na niskim poziomie mogą skutkować tą samą reakcją adaptacyjną, co mogłoby wyjaśniać na przykład wielość czynników przyczynowych w autyzmie. Autorzy wskazują na przydatność w rozważaniach zaburzeń rozwoju konceptualizacji trajektorii rozwoju w formie krajobrazu epigenetycznego Waddingtona. 
Postulują konieczność projektowania i podejmowania wczesnych interwencji, zanim główne objawy niektórych zaburzeń, mających początek w nietypowościach genetycznych, staną się częścią złożonych wzorców nieprawidłowości. Programy wczesnych interwencji powinny, jak podkreślają autorzy, uwzględniać aktualną wiedzę dotyczącą rozwoju poznawczego i rozwoju mózgu. Obecnie trudno jest ustalić, które elementy podejmowanych interwencji prowadza do sukcesu lub jego braku, ze względu na to, że większość programów jest ogólna, ukierunkowana zarówno na czynniki poznawcze, jak i niepoznawcze, a dokonywane pomiary dotyczą różnych skutków w różnym wieku.

Przewidując dalszy rozwój neurokognitywistyki rozwoju, autorzy podkreślają koniecz- ność współpracy pomiędzy neurobiologami rozwoju, badaczami rozwoju poznawczego i specjalistami w zakresie modeli obliczeniowych. Autorzy przewidują, że istotną rolę w rozwoju dyscypliny odegrają nowe metody badań, ale też konieczne będzie poszukiwanie wyjaśnień teoretycznych, spójnych względem poszczególnych poziomów wyjaśniania. Dobre teorie powinny podlegać testowaniu przez obserwacje zarówno na poziomie mózgowym, jak i behawioralnym, koncentrować się na mechanizmach zmiany, zachowywać kompatybilność ze złożonymi i dynamicznymi aspektami przetwarzania mózgowego oraz wyjaśniać różne jego poziomy. Ponadto autorzy zalecają wdrażanie teorii pod postacią działających modeli komputerowych.

\section{PRZYPIS}

${ }^{1}$ M.H. Johnson (2000), Functional brain development in infants: Elements of an interactive specialization framework. Child Development, 71(1), 75-81. 